\title{
Nutritional supplementation with non-conventional food resources and its effect on the productive parameters in rabbits *
}

\author{
Karen Gisela Sánchez-Bustos \\ Universidad de Cundinamarca, Facultad de Ciencias Agropecuarias, Fusagasugá, Cundinamarca - Colombia. \\ karensanchezudec@gmail.com \\ (1) https://orcid.org/0000-0002-8004-7/29 \\ Natalia Escobar-Escobar \\ Universidad de Cundinamarca, Facultad de Ciencias Agropecuarias, Fusagasugá, Cundinamarca - Colombia. \\ nataliaescobar@ucundinamarca.edu.co (D) https://orcid.org/0000-0002-2206-1432

\section{Sandra Marcela Castro-Ruiz} \\ Universidad de Cundinamarca, Facultad de Ciencias Agropecuarias, Fusagasugá, Cundinamarca - Colombia. \\ smcastro@unal.edu.co \\ (D) https://orcid.org/0000-0002-2655-834X
}

A B S T R A C T

The effect of diets with nonconventional forage resources, balu (Erythrina edulis) and giant taro (Alocasia macrorrhiza) was evaluated, on production parameters of New Zealand white rabbits (Oryctolagus cuniculus) under family farming production, in Silvania (Cundinamarca, Colombia). 36 weaned rabbits of 35 days old were used. They were distributed in 4 treatments (substitution of commercial pellets by giant taro leaves flour 25\% (Giant taro), balu 25\% (Balu); their mixture, giant taro 12.5\% and balu 12.5\% (GB), and a control with commercial pellets) with three repetitions each. Variables evaluated: initial weight at 35 days old, daily weight gain, consumption, feed conversion and final weight at 85 days old, carcass yield, haunch, loin and meat. Data was analyzed by Tukey multiple comparison test at $5 \%$ significance level, variance homogeneity and error independence verified by means of Shapiro-Wilks, Levene and Durbin-Watson tests, respectively, by R program. No significant differences were found in the final weight, on weeks 5 and 6 , which registered significant differences $(p<0.05)$, for giant taro $(1771.85 \pm 88.21 \mathrm{AB})$, control $(1933.06 \pm 88.20 \mathrm{~B})$, giant taro $(1935.05 \pm 91.26$ $A B)$, control $(2 \mid 44.42 \pm 91.26 B)$ respectively. Daily weight gain showed significant differences $(p<0.05)$ at week 5 for giant taro (33.56 $\pm 2.82 \mathrm{AB})$; control (.37 $\pm 2.825 \mathrm{~B})$. Significant differences were showed by most zootechnical variables $(p<0.05)$. The results showed that diets with nonconventional forage resources (balu and giant taro) are a viable alternative for animal feeding, due to their high nutritional content and as a by-product of commercial interest for rural families in areas of the middle Colombian tropics.

KEYWORDS

Feeding; sustainable production; lagomorph

Recibido: 25/05/2020 Aceptado: 18/I2/2020

* Este es un artículo Open Access bajo la licencia BY-NC-SA (http://creativecommons.org/licenses/by-nc-sa/4.0/)

Cómo citar este artículo: SÁNCHEZ-BUSTOS, Karen Gisela; ESCOBAR-ESCOBAR, Natalia; CASTRO-RUIZ, Sandra Marcela. Nutritional supplementation with non-conventional food resources and its effect on the productive parameters in rabbits. En: Entramado. Enero - Junio, 2021 vol. 17, no. I, p. 262-270 


\title{
Suplementación nutricional con recursos alimenticios no convencionales y su efecto sobre los parámetros productivos en conejos
}

\begin{abstract}
Se evaluó el efecto de dietas con recursos forrajeros no convencionales, chachafruto (Erythrina edulis) y bore (Alocasia macrorrhiza), sobre parámetros productivos de conejos raza nueva Zelanda blanco (Oryctolagus cuniculus) bajo producción de agricultura familiar en Silvania (Cundinamarca, Colombia). Se utilizaron 36 conejos destetos de 35 días, los cuales fueron distribuidos en 4 tratamientos (sustitución de concentrado comercial por harinas de hojas de bore 25\% (Bore), chachafruto 25\% (Balu), su mezcla bore $12.5 \%$ y balu $12.5 \%$ (BB) y un control con concentrado comercial) con tres repeticiones cada uno. Se evaluaron variables como: peso inicial a los 35 días, ganancia diaria de peso, consumo, conversión alimenticia y peso final a los 85 dias de edad, rendimiento en canal, anca, lomo, carne. Los datos fueron analizados mediante la prueba de comparación múltiple de Tukey con significancia del 5\%. La varianza, homogeneidad y error fueron verificados por la prueba de Shapiro-Wilks, Levene y Durbin-Watson, utilizando el programa R. No se encontraron diferencias significativas en el peso final,

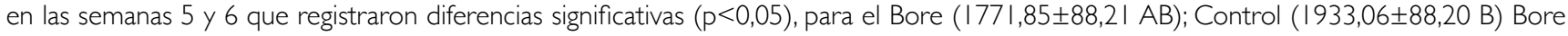
$(1935,05 \pm 91,26 \mathrm{AB})$; Control $(2144,42 \pm 91,26 \mathrm{~B})$ respectivamente; la ganancia diaria de peso presentó diferencias significativas $(p<0,05)$ en

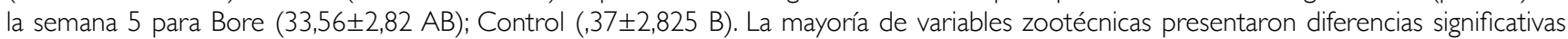
$(p<0,05)$. Los resultados obtenidos demostraron que las dietas con recursos forrajeros no convencionales (chachafruto y bore) son una alternativa viable para la alimentación animal por su alto contenido nutricional y como subproducto de interés comercial para familias rurales de zonas del trópico medio colombiano.
\end{abstract}

Palabras clave

Alimentación; producción sostenible; lagomorfo

\section{Suplemento nutricional com recursos alimentares não convencionais e o seu efeito sobre e o seu efeito nos parâmetros produtivos dos coelhos}

RES U M O

Foi avaliado o efeito das dietas com recursos forrageiros não convencionais, chachafruit (Erythrina edulis) e bore (Alocasia macrorrhiza), nos parâmetros produtivos dos coelhos brancos da Nova Zelândia (Oryctolagus cuniculus) sob produção agrícola familiar na Silvânia (Cundinamarca, Colômbia). Foram utilizados 36 coelhos desmamados de 35 dias, que foram distribuídos em quatro tratamentos (substituição do concentrado comercial por farinha de folha de furo 25\% (Bore), chachafruit 25\% (Balu), a sua mistura de furo I2,5\% e balu 12,5\% (BB) e um controlo com concentrado comercial) com três réplicas cada. Foram avaliadas as seguintes variáveis: peso inicial aos 35 dias, ganho de peso diário, ingestão de alimentos, conversão alimentar e peso final aos 85 dias de idade, rendimento da carcaça, alho, lombo e carne. Os dados foram analisados pelo teste de comparação múltipla de Tukey com um significado de 5\%. A variância, homogeneidade e erro foram verificados pelo teste Shapiro-Wilks, Levene e Durbin-Watson, utilizando o programa R. Não foram encontradas diferenças significativas no

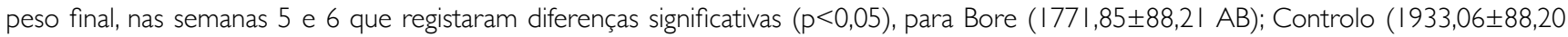

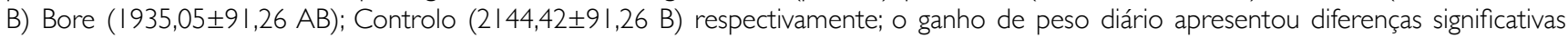
$(p<0,05)$ na semana 5 para Bore $(33,56 \pm 2,82 A B)$; Controlo $(, 37 \pm 2,825$ B). A maioria das variáveis zootécnicas apresentou diferenças significativas $(p<0,05)$. Os resultados obtidos mostraram que as dietas com recursos forrageiros não convencionais (chachafruit e bore) são uma alternativa viável para a alimentação animal devido ao seu elevado conteúdo nutricional e como subproduto de interesse comercial para as famílias rurais nas zonas meio-tropicais colombianas.

Palavras-chave

Alimentação; produção sustentável; lagomorfo 


\section{Introducción}

Hunger and poverty are problems faced by the rural sector today. It has been estimated that almost half of the rural population is poor and a third live in extreme poverty; most of the farmers work in small-scale agriculture as their main means of subsistence, based on family labor (FAO, Regional Office for Latin America and the Caribbean, 2017), and are classified as "agricultural producers, livestock farmers, foresters, small scale fishermen and resource-limited fish farmers".

In Colombia, one of the livestock activities developed within family agriculture is rabbit breeding, defined as "reproduction process in an economic way, aimed at obtaining maximum profit from the sale of products and by-products of rabbit breeding and fattening" (Never, 2018), as quoted by Vargas and Castilla (20II). It has been a promising activity for the generation of animal protein of excellent quality in developing countries where most of the food production is generated by farmer families with $79 \%$ participation in food generation for household consumption, contributing to the country's food self-sufficiency (Comité Nacional de Impulso Colombia, 2014). Rabbit breeding as well as other livestock production has been affected by the continuous increases in cost of conventional raw materials such as grains and cereals, about which Silva et al, 2000; Retore et al, 2008 (as quoted Al-Dobaid, 2010), state that diets based on corn flour and soybean increase meat production costs (Bonilla, Delgado y Mora, 2016), generating in turn, a rise in human food prices since much of the grains are the main components of industrial foods.

In recent years, new nonconventional forage alternatives for animal feed that do not compete with human feeding and are readily available in the environment have been sought (Calvache, 2005; Palma and Hurtado, 2009), such as giant taro (Alocasia macrorrhiza) and balu (Erythrina edulis), forage plants with multiple benefits. Commercial rabbit production has been adversely affected by the high cost of feeding and use of traditional feed stuff (grain and soya bean) that have direct competition with humans for food. There has been an unbearable continued increase in the cost of traditional feed resources (soya been, maize, millet, groundnut, fish meal etc.). Diverse plant materials and industrial byproducts in different agro ecological regions of the world have been assessed for their nutritive potentiality as alternative feedstuff ingredients, these include: water spinach (Hongthong, Siton, Chhay y Preston, 2004), wheat bran (Falcao-e-Cunha, Peres, Joao y Castro-Solia, 2004), rape seed (Gasim-Boubaker et al., 2007), gliricidial leaf meal (Amata and Bratte, 2008), groundnut haulms and cowpea and Preston, 2009), olive pulp (Mehrez and Mousa, 201 I), sweet potato fodder (Elamin et al., 20I2), white lupin grain (Zwolinski et al., 2017) etc. the list is inexhaustible because the nature of local feedstuff depends on geographical ecological regions and plants resources.

The objective of this research was to evaluate the effect of diets with nonconventional forage resources, balu (Erythrina edulis) and giant taro (Alocasia macrorrhiza), on productive parameters of New Zealand white rabbits (Oryctolagus cuniculus) under family farming production in Silvania (Cundinamarca).

\section{Materials y methods}

\section{Location and description of the area}

This research was conducted on Lusitania farm, Santa Rita village, municipality of Silvania, Cundinamarca, in the Sumapaz region, $49 \mathrm{~km}$ from the city of Bogota, I,850 m.a.s.l, average temperature between $17^{\circ}$ and $20^{\circ} \mathrm{C}, 85 \%$ annual relative humidity, I,653 $\mathrm{mm} /$ year rainfall. The municipality has a total area of $163 \mathrm{~km} 2$ of which $7.48 \mathrm{~km}^{2}$ are urban areas and $155.44 \mathrm{~km} 2$ are rural (Castellon, 20I4).

\section{Animals and Equipment}

36 white New Zealand rabbits of 35 days old were used; they were housed in 8 galvanized cages with $0.5 \times 0.5 \times$ $0.4 \mathrm{~m}$ dimensions, metal troughs and automatic drinking troughs (Henao, Gutierrez and Oviedo, 2012; Bonilla, Delgado and Mora, 2016).

\section{Diet elaboration}

Diets based on balu (Erythrina edulis) and giant taro (Alocasia macrorrhiza) leaves flour, were carried out as reported by Gutierrez, Henao and Oviedo (20l4).

\section{Processing of biological material}

\section{Cutting}

A 4 year-old giant taro culture and a 6 year-old balu culture were used. Regarding giant taro, 45 to 50 day-old bud leaves were cut, that is to say, those with a green brilliant color; leaves with brown or yellow spots were not used, and care was taken when cutting the leafstalk, with a cut in diagonal near the stem or corm. Regarding balu, young leaves of all the tree stratum were cut. Besides, a straw chopper was used to reduce the particles size, which allowed better drying of the material. Next, drying was done on a forced air circulation stove for 48 hours, at $65^{\circ} \mathrm{C}$ to ensure lower humidity without altering the compositional quality of the plant material. 


\section{Pellet Processing}

Using giant taro (Alocasia macrorrhiza), balu (Erythrina edulis) flour and commercial pet food, pellets were made for each diet:

- Mix of raw materials to obtain homogenization and according to the proportions regarding the diet set.

- Homogenization: according to the methodology used by Gutierrez, Henao and Oviedo (2014), raw material was mixed and then moistened with a water solution and molasses at $50^{\circ} \mathrm{Bx}$, until a homogeneous structure was obtained

- Artisanal pelletizing in an industrial pelletizer of the nutrition laboratory of the University of Tolima.

- Pellet drying at room temperature.

\section{Diets implementation and their corresponding} treatment

Diets corresponding to the different treatments are described below:

- TI: Commercial food (Control)

- T2: Commercial food (75\%) with addition of $25 \%$ giant taro flour

- T3: Commercial food (75\%) with addition of $25 \%$ balu flour

- T4: Commercial food (75\%) with addition of a mixture of giant taro (12.5\%) and balu (12.5\%) flour.

\section{Chemical analysis of flour}

$500 \mathrm{~g}$ flour were obtained at random for each raw material and diet. The flour was packed in hermetic bags with their corresponding identification; then the samples were sent to Laserex laboratory of the University of Tolima, to determine by means of a bromatological analysis, the percentages of nutrients contributing: dry matter (DM), crude protein (CP), crude fiber (CF), neutral detergent fiber (NDF), acid detergent fiber (ADF), ethereal extract (EE) and ashes (AS), according to the methodology described by AOAC (1995), (Acosta et al. (2016).

\section{Feed frequency}

The rabbits were fed according to the diet established for each treatment. The food required was provided in two daily rations, according to their age: at 7:30 am in the morning, and at 4:30 pm in the afternoon because according to Read et al. (2016), although rabbits have a limited feeding behavior, they can consume pelleted food quickly, which generates a hunger state during part of the day, creating stereotypical behavior to famine and the frustration for not consuming forage.

\section{Productive Parameters}

Production parameters evaluated during the experimental period:

- Initial live weight (ILW): which was measured on day 35 , when rabbits were weaned. Each one was weighed and the initial average weight of each treatment was determined.

- Final live weight (FLW): it was determined at week 8 post-weaning, when the experimental period ended; each rabbit was weighed on a digital scale to determine the final average weight of each treatment.

- Average Daily Weight Gain (ADWG): According to Palma and Hurtado (20I0), it was determined, based on the weekly weight gain divided into the 7 days of the week, which resulted in the weight gain in grams gained by a rabbit in 24 hours.

- Feed consumption: it was determined by weighing the food supplied daily minus the food not consumed (rejected) for each treatment.

- Feed conversion: According to (Cano and Dohigo, 2012) it is a practical measure to calculate the efficiency with which animals use the food ingested for their growth, which is calculated through De Blas 1989's formula, quoted by Palma et al, 2010. Feed consumption divided by final weight, minus initial weight, and it is expressed in $\mathrm{kg}$ of food consumed per $\mathrm{kg}$ live weight (LW).

- All the parameters listed above were taken every week on a specific day, with the time settled during the whole experimental period.

\section{Animal slaughter}

The rabbits were slaughtered to determine the parameters of productive quality. Slaughter was carried out by the numbing method described by Rodriguez (2002); the rabbits were gutted and quartered immediately after slaughter, a process in which the head, hands, legs, skin and viscera were removed.

\section{Statistic Analysis}

Productive parameters were initially analyzed by means of variance analysis (ANOVA) at a $95 \%$ accuracy level, a Tukey multiple comparison test at $5 \%$ significance level, and an orthogonal contrast between the control treatment (TI) and the other treatments. A multivariate analysis of variance (MANOVA) was carried out to evaluate whether there 
was any treatment showing a better behavior, regarding the productive parameters as a whole. And Hotelling comparison test was carried out at a significance level of $5 \%$. The previous tests being accepted only if they fulfilled the assumptions of normality, variance homogeneity and error independence verified by means of Shapiro-Wilks, Levene and Durbin-Watson tests, respectively.

\section{Results and Discussion}

\section{Flour nutritional contribution}

Table I shows the nutritional composition of balu leaf flour (Erythrina edulis) y and giant taro leaves flour (Alocasia macroorrhiza)

Table I.

Nutritional composition of balu leaves flour (Erythrina edulis) and giant taro leaves flour (Alocasia macroorrhiza).

\begin{tabular}{ccc}
\hline Indicators & H. Balu & H. Giant taro \\
\hline Dry matter \% & 89.8 & 86.2 \\
Protein \% & 20.3 & 17.3 \\
Fiber \% & 29.3 & 11.0 \\
Ash \% & 9.21 & 11.7 \\
Ethereal extract \% & 1.83 & 4.3 \\
Calcium \% & 0.34 & 1.6 \\
Sodium $\mathbf{~ m g / k g ~}$ & 342.6 & 702.8 \\
Potassium \% & 1.27 & 1.74 \\
Magnesium \% & 0.06 & 0.13 \\
Copper $\mathbf{~ m g / k g ~}$ & 9.8 & 10.5 \\
Zinc mg/kg & 28.5 & 39.4 \\
Iron mg/kg & 457 & 128.3 \\
Manganese mg/kg & 35.6 & 96.5 \\
Boron mg/kg & 142.6 & 105.3 \\
Phosphorus \% & 0.32 & 0.43 \\
Sulfur \% & 0.28 & 0.25 \\
\hline
\end{tabular}

Source: The authors

Additionally, this tables shows the nutritional composition of the raw materials used in the experiment, which were determined by bromatological analysis according to the methodology described by the AOAC (1995).

As for the nutritional contribution of the flours of the legumes used, it can be stated that balu is a tree legume native of the Andean region and used by the ancestors in human and animal feeding, due to the high contents of nutrients present in the fruits and leaves. Inciarte et al (20I5), reported an update of the nutritional content of protein contribution, $29 \%$ fiber, $3 \%$ ethereal extract and $9 \%$ ash, similar results to those found by Delgado and Albarracin (2012) which evaluated the compositional contribution of balu flour, obtaining $22.8 \%$ proteins and $0.70 \%$ fat percentage as possible extenders for meat products.

Furthermore, the nutritional composition of giant taro (Alocasia Macroorrniza), although a little lower compared to balu, also showed high content of proteins and essential amino acids. This fabaceous species has been used in the feeding of pigs, birds and fish. Mora - Valverde (20I5) reported a protein and fiber content was $22.4 \%$ and $15.4 \%$ respectively. Similar result to that reported by Basto Gomez (1995) where the percentage of protein is $21.0-22.0 \%$, higher than that found by Moreno (2002) with protein levels between $13.6 \%$ and $15.4 \%$, which are lower than those reported in this research. As for ethereal extract, Muñoz Valderrama (20II) showed levels of $3.1 \%$ in whole giant taro leaves, a lower value than the one found in this study, while fiber found in giant taro leaves represents $15.4 \%$.

The productivity of the different animal species depends to a great extent on the nutrients provided by the supplied diet, in the case of this research it can be mentioned that the percentage of protein provided by the Giant taro and Balu, it is significant since comparing it with another type of food used in rabbit production, is above the reported values (Aguda and Omage, 2014), indicating that they are a promising alternative for animal feeding; Likewise, the importance of the nutritional quality of the different vegetable raw materials can be shown, since the content of fiber, lignin, minerals and proteins are keys to success in weight gains, growth rates behavior and reproductive performance, among others (Lee, 2018). Table 2 shows the bromatological composition of the diets provided in each treatment.

Table 2.

Bromatological composition of the diets provided in each treatment. DIETS

\begin{tabular}{ccccc}
\hline PARÁMETERS & $\begin{array}{c}\text { GIANT } \\
\text { TARO }\end{array}$ & BALU & GB & CONTROL \\
\hline Dry matter \% & 94 & 95 & 81.3 & 86.2 \\
Protein \% & 16.4 & 17.4 & 19.1 & 17.3 \\
Fiber\% & 14.3 & 16.6 & 18 & 11 \\
Ethereal & 10.3 & 9.3 & 0.8 & 4.3 \\
extract\% & & & & \\
Ash \% & 10 & 8.2 & 9.9 & 10.7 \\
\hline
\end{tabular}

Source: The authors

An increase in the percentage of dry matter and the ether extract is observed in comparison to Table I, for the values of fiber and protein, a decrease in the percentage of these components was observed in the different diets. 
In the case of the dry matter (DM) content (\%) of rations from different trataments ranged from 94 to 86.2 para and showed no difference among the treatments.

According to the study, the percentage of protein for the Giant Taro + Balu (GB) treatment is the highest with respect to the other treatments, however there was no significant difference, therefore, to consider the GB diet as a good source of protein, the inclusion level must be considered, since as the amount of raw material increased, the protein also increased.

The protein percentage of the Giant Taro, was lower than reported by Girata, Lozano, Tarazona, Aguilar and San Miguel (2013) who found protein contents of up to $25 \%$ in the Giant Taro leaves and also reported 10\% fat content and high concentrations of $\mathrm{A}, \mathrm{C}$ vitamins and minerals, are results close to those reported in this research that indicate that the Giant taro is a plant that has special characteristics to be used in feeding birds and other livestock productions.

\section{Production parameters}

\section{Post-slaughter Parameters}

At the end of the experimental period at 90 days old, the rabbits showed a final weight or a live weight at slaughter higher than $2 \mathrm{~kg}$ (Table 3), an internationally established value for marketing rabbits in fattening (Ortiz, Motta. Anchieta, Moraes y Lezcano, 2013).

Table 4 shows the variables related to the characteristics of the carcass of rabbits fed with diets containing $25 \%$ giant taro leaf flour, balu and their mixture. As for carcass yield variable $(C Y)$, no significant differences were observed in the giant taro treatment, relative to control treatment. However, significant differences were observed $(p<0.05)$ for giant taro and control treatments, regarding balu and GB. Also, the carcass length showed difference $(p<0.05)$.

Table 3.

Productive behavior of rabbits fed with diets containing $25 \%$ giant taro and blu leaves and their mixture.

\begin{tabular}{|c|c|c|c|c|c|}
\hline \multirow[b]{2}{*}{ VARIABLES } & \multicolumn{4}{|c|}{ TREATMENTS } & \multirow[b]{2}{*}{ P- Value } \\
\hline & Giant taro & Balu & GB & Control & \\
\hline Initial weight $(g)$ & $720 \pm 17.27^{a}$ & $670.6 \pm 17.27^{a}$ & $694 \pm 17.27^{a}$ & $704.3 \pm 17.27^{a}$ & $0.0379^{* *}$ \\
\hline Final weight (g) & $2067.4 \pm 95.12^{\mathrm{a}}$ & $2078.4 \pm 99.15^{a}$ & $2022.3 \pm 91.9^{a}$ & $2363.3 \pm 95.11^{a}$ & 0.062 \\
\hline Weight daily gain (g/d) & $22.54 \pm 2.09^{a}$ & $29.46 \pm 2.23^{\mathrm{ab}}$ & $26.42 \pm 2.09^{\mathrm{ab}}$ & $33.34 \pm 2.23^{b}$ & $0.008^{* * *}$ \\
\hline Weight daily gain week 5 (g/d) & $33.56 \pm 10.7^{a b}$ & $27.53 \pm 10.7^{a}$ & $25.23 \pm 10.7^{a}$ & $38.37 \pm 10.7^{\mathrm{ab}}$ & $0.008^{* * *}$ \\
\hline weight gain week $\mathbf{5}(\mathrm{g})$ & $1771.35 \pm 338^{a b}$ & $1644.83 \pm 338^{a b}$ & $1568.10 \pm 338^{a}$ & $1933.06 \pm 338^{a}$ & $0.0398^{* *}$ \\
\hline weight gain week 6 (g) & $1935.05 \pm 349^{a b}$ & $1848.24 \pm 349^{\mathrm{ab}}$ & $1744.39 \pm 349^{a}$ & $2144.42 \pm 349^{b}$ & $0.0312^{* *}$ \\
\hline Feed consumption (g/d) & $127.24 \pm 5.8^{a}$ & $145.2 \pm 5.8^{a}$ & $141.6 \pm 5.8^{a}$ & $123.8 \pm 5.8^{a}$ & 0.446 \\
\hline Feed conversion $(\mathrm{g} / \mathrm{d})$ & $3.1 \pm 0.23^{a}$ & $3.4 \pm 0.23^{a}$ & $3.6 \pm 0.23^{a}$ & $2.6 \pm 0.23^{a}$ & 0.090 \\
\hline
\end{tabular}

Source: The authors

Values with different letters within the same row indicate statistically significant differences $(p<0.05)$,

Table 4.

Characteristics of the carcass of rabbits fed with diets containing 25\% giant taro and balu leaf flour and their mixture.

\begin{tabular}{|c|c|c|c|c|c|}
\hline \multirow[b]{2}{*}{ VARIABLES } & \multicolumn{5}{|c|}{ TREATMENTS } \\
\hline & Giant taro & Baru & GB & Control & P- Value \\
\hline Carcass yield (\%) & $49.54 \pm 0.57^{b}$ & $46.95 \pm 0.57^{a}$ & $46.19 \pm 0.53^{a}$ & $49.54 \pm 0.57^{b}$ & $0.003^{* * *}$ \\
\hline Carcass length (CM) & $34.93 \pm 0.51^{\mathrm{ab}}$ & $34.50 \pm 0.55^{\mathrm{ab}}$ & $32.94 \pm 0.48^{a}$ & $38.85 \pm 0.48^{b}$ & $0.003^{* * *}$ \\
\hline Haunch yield (\%) & $31.22 \pm 1.35^{a}$ & $29.64 \pm 1.35^{a}$ & $32.63 \pm 1.26^{a}$ & $30.70 \pm 1.35^{a}$ & 0.453 \\
\hline Loin yield (\%) & $24.00 \pm 0.77^{a}$ & $22.72 \pm 0.77^{a}$ & $23.55 \pm 0.72^{a}$ & $24.61 \pm 0.72^{a}$ & 0.374 \\
\hline
\end{tabular}

Source: The authors

Values with different letters within the same row indicate statistically significant differences $(p<0.05)$ 
Final weight (FW), feed consumption and feed conversion $(F C)$, did not show significant differences $(p<0.05)$ between treatments; however, differences $(p<0.05)$ for weight variable at weeks 5 and 6 in giant taro treatment $(177 \mid .85 \pm 88.2 I$ $A B)$ were found; and control $(1933.06 \pm 88.20 \mathrm{~B})$, giant taro

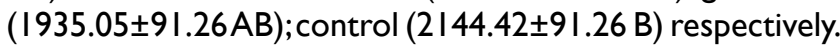
Daily weight gain showed significant differences $(p<0.05)$ in week 5 for giant taro $(33.56 \pm 2.82 \mathrm{AB})$, control $(.37 \pm 2.82$ $B)$. Direct relationship with the rabbits productive behavior was revealed by data on the bromatological composition of the diets provided in each treatment. It was observed that the growth of rabbits distributed in the different treatments could be affected by the crude fiber content of these diets, and (Quintero, García and Peláez, 2007), state that the amount of fiber recommended is 10 to $15 \%$ for growth and normal intestinal functioning; therefore, diets with higher fiber values increase when passing through the intestine, reducing nutrients digestibility and absorption, affecting feed conversion and daily weight gain up to $30 \%$ to 50\% (Trocino et al., 2013). However, Gidenne et al. (2017) state that diets with more than $25 \%$ fiber in acid detergent (FDA) reduce food consumption, preventing the supply of digestible energy needs for an optimal growth rate. In contrast, when fiber is reduced by less than $18 \%$, rabbits can develop digestive pathologies; mucoid enteritis and coccidiosis.

Victoria et al. (2007) evaluated golden button flour (Tithonia diversifolia) in three inclusiom levels of $15 \%, 30 \%$ and $40 \%$, in diets for rabbits in growth stage, which presented a $14.3 \%$ crude fiber and $16 \%$ crude protein composition, finding significant differences $(p<0.05)$ between treatments for the variable weight gain with $19.1 \mathrm{~g} /$ day and a 4.6 feed conversion, similar to that reported by Yasmania and Dihigo, (2012), who determined the productive behavior of rabbits fed with a $20 \%$ inclusion of dolicho and mucuna flour did not find significant differences between treatments. Feed conversions 4.56 are greater than those reported in this study.

On the other hand, $21.25 \mathrm{~g} / \mathrm{rabbit} /$ day daily weight gain in these experiments is similar to those obtained with the inclusion of flour from fruits and breadfruit leaves (Artocarpus altilis) in the fattening of $19 \mathrm{~g} /$ day white $\mathrm{New}$ Zealand rabbits (Leyva, Valdivie and Ortiz, 2012), being lower than those determined in this experiment. According to Lukefahr and Cheeke (quoted by Pronaf, 2012), daily weight gains obtained are adequate because rabbits bred in temperate regions have daily gains in the range of 30 to $40 \mathrm{~g} /$ day, while those bred in warm temperatures vary from 10 to $20 \mathrm{~g}$.

Protein percentage in diets is adequate for the requirements 268 present additional benefits; on the contrary, the incidence of enterotoxemias occurring when $20 \%$ is exceeded increases. It has also been suggested that high levels of this nutrient increase this metabolic problem and favors the proliferation of Clostridium spp. and E. coli (Mora-Valverde, 2010).

The nutritional content of different diets directly influences different parameters; carcass yield $(C Y)$ is an indicator that allows determining the productivity of an individual within a production. According to Leyva, Valdivie and Ortiz (2012) rabbits slaughtered at a young age present a reduction in carcass yield because this indicator tends to increase with age as muscle tissue has greater development; however, fat content is higher than that in young animals carcasses. Calvache (2005) evaluated rabbit feeding with mulberry supplied adlibitum, presenting $46.6 \%$ average carcass yields, similar to those reported by Leyva, Valdivie and Ortiz, (2012), who included fattening fruit flour and bread tree leaves in the rabbit serving size, finding $49.29 \% \mathrm{CY}$ at 90 days old. Likewise, Lara, Itza, Sanginés y Magaña (20I2), fattened rabbits with mulberry or tulip flour included in multinutritional blocks, obtaining 50\% CY.

The Spanish rabbit breeding organisation (ASESCU) points that rabbits fed with commercial pellets reach carcass yield ranging between 50 to $65 \%$, based on the animals' age (Galeano, 2017). However, rabbits fed with nonconventional raw material obtain a $\mathrm{CY}$ between $46 \%$ to $50 \%$ approximately, similar to that reported in this study. Variation in carcass yield can be influenced by the specimens age and the dietary nutrients availability. Molina et al. (2017) estimated the characteristics of the carcass in rabbits fed with Amaranthus Dubius, finding average value of $28.41 \%$ for loin yield and $39.28 \%$ for haunch. Also,Adeyemo, Taiwo and Adeyemi (20I4), obtained $28.8 \%$ haunch yields in rabbits fed with forages. This value is lower than the one reported in this study.

On the other hand, morphometric measures are used to evaluate breed yields, predict live weight gain and they are also a productive yield indicator, Chineke (quoted by Galeano, 2017).

\section{Conclusions}

Rabbits fed with giant taro diet presented greater development and growth than those fed with balu; also, significant differences $(p<0.05)$ for the weight variable in week 5 and 6 were observed. From here, it can be concluded that giant taro can be used as unconventional raw material in food manufactoring for rabbits in growth until week 6 .

Giant taro is a non-conventional raw material that generates more gain in diets for rabbit feeding with $25 \%$ substitution 
of the commercial pellet. Besides, this diet did not present significant differences in productive variables regarding the treatment control (commercial pellet), being an alternative for the elaboration of rabbit feed with native raw material available in the region, which do not compete with human food and will promote sustainable agricultural production.

There are many unconventional fruits and foods available in the tropic land and they represent valuable sources of nutrients; thus, Giant taro and Balu appear as outstanding protein sources. However, the interest in a fruit or a non-conventional food for animal feed, will depend on its availability, flavor, acceptance by the species and the quantity to offer to cover its requirements; in this investigation the results showed that diets with nonconventional forage resources (balu and giant taro) are a viable alternative for animal feeding, due to their high nutritional content and as a by-product of commercial interest for rural families in areas of the middle Colombian tropic.

\section{Conflict of interests}

The authors have no conflicts of interest to declare.

\section{References}

I. ACOSTA-ACOSTA, Yanixi; LA-O-MICHEL, Ángel Luis; VALDIVIÉNAVARRO, Manuel Isidoro; CANTALAPIEDRA-BELL, Jaqueline. Digestibility of Diets With Growing Levels of Defatted Coconut Flour in Growing Rabbits. In: Ciencia y Agricultura. Feb. 2018. vol I5, no. I, p. 45-5I.https://doi.org//0.19053/01228420.vI5.nI.2018.7755

2. ADEYEMO, Adebowale A;TAIWO, O. S.; ADEYEMI, Olajide Ayorinde Performance and carcass characteristics of growing rabbits fed concentrate to forage ratio. In: Modern Plant \& Animal Sciences. 20I4. vol. 2 n. I P 33-4I. http://www.modernscientificpress. com/Journals/ViewArticle.aspx? ON7biMb70/X7VmC9bFLLWR/ SGstX+GKwilifVTiWQhRev4XJRMSONSxx64U8uiuQ

3. AGUDA, A. Y; OMAGE, J. J. Effect of feeding different processed pigeon pea (Cajanus cajan) supplemented with Maxigrain ${ }^{\circledR}$ on the performance and carcass characteristics of weaner rabbits. 2014. In: Journal of Animal and Poultry Sciences. vol 3. n. 2 p 3846. http://www.japsc.com/wp-content/uploads/2014/09/AgudaJAPSC-2014-3_2_-38-46.pdf

4. AL-DOBAIB, S. N. Effect of diets on growth, digestibility, carcass and meat quality characteristics of four rabbit bree. In: sauidi journal of biological sciences. 2010. p. 83-93. https://doi.org/10.1016/j. sjbs.2009.12.012

5. AMATA, IA.; BRATTE, L. The effect of partial replacement of soybean meal with gliricidia leaf meal on the performance and organ weights of weaner rabbits in the tropics. In:Asian J.Anim. Vet.Adv. 2008. vol. 3, no 3. p 169-173. https://doi.org//0.3923/ajava.2008.169.173

6. BASTO GÓMEZ, Gustavo. El Bore. Características botánicas, sistemas de cultivo y valor alimenticio en la producción porcina. 1995. Cartilla, CORPOICA, Santafé de Bogotá, Colombia. https:// repository.agrosavia.co/handle/20.500.12324/2080

7. BAWA, G.S.;AJIDE, S.O.;ADEYINKA, I.A.;AJALA, M.K. Effect of varying levels of groundnut haulms and cowpea shells on the performance weaned rabbits. In:Asian J.Anim.Vet.Adv. 2008. no 3. p 54-6I. https:// doi.org// 0.3923/ajava.2008.54.61

8. BONILLA-VIVAS, Carlos Eduardo; DELGADO-ACEVEDO, Luis Alexander; MORA, Robert Emilio; HERRERA, Ana María. Effect of increasing levels of Arachis pintoi foliage in diets for rabbits on the zootechnical performance in the growth-fattening phase. In: Revista Científica FCV-LUZ. 2016. vol 26. no I, p. 41-48. http://www.saber.ula. ve/handle//23456789/4I764

9. CARO, Yasmani; DIHIGO, Luis E. Performance traits of rabbits fed diets with dolicho and mucuna integral meal. 2012. In: Rev. Unell. Cienc. Tec. vol 30. p. 29-35. https://www.researchgate.net/ publication/273129559 Performance traits of rabbits fed diets with_dolicho_and_mucuna_integral_meal

10. CASTELLON, J. Silvania mi municipio, mi cultura . Obtenido de Alcaldia de Silvania cundinamarca: http://silvania-cundinamarca.gov. co/apc-aa-files/34326|65356/38646/306/6666626/37/monografiade-silvania-mi-municipio-mi-cultura-por-jairo-melo.pdf 2I Feb 2014

II. COMITÉ DE IMPULSO NACIONAL. ORGANIZACIÓN DE LAS NACIONES UNIDAS. 2015. Obtenido de FAO: http://www.fao.org/ family-farming/detail/es/c/319830/

12. DELGADO C., Natalia;ALBARRACÍN H.,William. Microestructura y propiedades funcionales de harinas de quinua (chenopodioum quinoa w ) y chachafruto (erythrina edulis): potenciales extensores cárnicos. En: Vitae. 20I2. vol. 19 n. I, p S430-S432. https://www.redalyc.org/ pdf//698//698239/4I35.pdf

13. ELAMIN, K.M.; ELKHAIREY, M.A.; BAKHIET, A.O.; AHMED, H.B.; MUSA, A.M. Carcass and non-carcass traits of local rabbits fed different sources of fodder in Sudan. En:Asian J.Anim. Vet. Adv. 2012. no 7. p 34I-345. https://doi.org/10.3923/ajava.2012.341.345

14. FALCAO-E-CUNHA, Luisa; PERES, Helena; FREIRE, João P. B.; CASTRO-SOLLA, Luís. Effects of alfalfa, wheat bran or beet pulp, with or without sunflower oil on caecal fermentation and on digestibility in the rabbit. In: Anim. Feed Sci. Technol. 2004. vol. I I7, n. I-2 p I3 I149. https://doi.org/10.1016/j.anifeedsci.2004.07.014

15. FAO. Oficina regional de la FAO para América Latina y el Caribe. Obtenido de agricultura familiar y sistemas alimentarios inclusivos para el desarrollo rural sostenible. (23 de octubre de 2017): http:// www.fao.org/americas/prioridades/agricultura-familiar/es/

16. GALEANO DÍAZ, Paola. Comportamiento productivo y características de la canal de conejos en crecimiento-finalización alimentados con dietas suplementadas con una proteasa (Bacillus Licheniformes).Tesis de pregrado. Universidad de Cundinamarca. 2017 http://repositorio.ucundinamarca.edu.co/handle/20.500.12558/330

17. GASIM-BOUBAKER, Aziza; ABDOULI, Hedi; HICHI, M. El; FAIZA, K.; TAYACHI, L. Feeding rapeseed meal to rabbits: Digestability, performance and carcass characteristics. In: Asian Journal Animal and Veterinary Advances. 2007. vol. 2 no I. p 38-4I. https://doi. org//0.3923/ajava.2007.38.41

18. GIDENNE, Thierry; GARREAU, Herve; DROUILHET, Laurence; AUBERT, C; MAERTENS, L. Improving feed efficiency in rabbit production, a review on nutritional, tecchnico-economical, genetic and environmental aspects. In: Animal Feed Science and Technology. 2017.p 109-122. https://doi.org/10.1016/j.anifeedsci.2017.01.016

19. GIRATÁ, Edison Andrés; LOZANO, Lina Patricia; TARAZONA, Andrea Milena; AGUILAR, Olga Ximena y SANMIGUEL, Edis Mauricio. Evaluación del crecimiento de pollos criollos mediante dietas elaboradas con productos de la región en dos localidades: Socorro y Charalá de Santander. Fase III. En: Revista Innovando en la U. Universidad Libre. 2013. No. 5. https://revistas.unilibre.edu.co/ index.php/innovando/article/view/3844 
20. GUTIÉRREZ G, Nelson; HENAO C, Jose Dubán; OVIEDO R., Oscar Mauricio. Methodology for Pellets building with Coffee and Cocoa derivates. In: Entornos. 2014. no 28. p 24. https://journalusco.edu.co/ index.php/entornos/article/view/520/984

21. HENAO C., Jose Dubán; GUTIÉRREZ G., Nelson; OVIEDO R, Oscar Mauricio. Use of agricultural by-products for rabbit feeding during fattening and breeding stages. In: Biotecnología en el Sector Agropecuario y Agroindustrial. 20I2. vol 10 no. 2. p 236 - 242. https:// revistas.unicauca.edu.co/index.php/biotecnologia/article/view/8II

22. HONGTHONG, Phimmmasan; SITON, Kongvongxay; CHHAY, Ty; PRESTON, T.R. Water spinach (Ipomoea aquatica) and Stylo 184 (Stylosanthes guianensis CIAT I84) as basal diets for growing rabbits. In: Livest. Res. Rural Dev. 2004. no 16. https://www.Irrd.cipav.org.co/ Irrd 17//0/chat 17109.htm

23. INICIARTE, Ingrid; PÉREZ, Antonio; HERNÁNDEZ, Erick; SANDOVAL, Claudia; OTÁLORA-LUNA, Fernando; MÁRQUEZ, Mariella; PÁEZ-RONDÓN, Oscar. Presence of the chachafruto (Erythrina edulis Triana ex Micheli) in the state of Merida, Venezuela. En: Revista Electronica Conocimiento Libre y Licenciamiento. 2015. No 10 p 140 - 153 https://www.academia.edu/22775695/ Presencia_del chachafruto_Erythrina_edulis_Triana_ex_Micheli en_el_estado_Merida_Venezuela

24. INTHAPANYA, Sangkhom; PRESTON, T.R. Effect of supplementation with sweet potato root and paddy rice on growth performance of local rabbits fed water spinach (Ipomoea aquatic) and paper mulberry (Broussonetia papyrifera) as basal diets. In: Livestock Research for Rural Development October, 2009. vol 21.n. 10. http://www.Irrd.org/ Irrd21//0/sang21176.htm

25. LARA y LARA Pedro Enrique; ITZÁ, Mateo F; SANGINÉZ-GARCIA, José Roberto; MAGAÑA, M.A. Morus alba and Hibiscus rosasinensis as partial substitute of soybean in rabbit's diets. In: Avances en investigación agropecuaria. January 2012. vol 16. p 9-19. http:// ww.ucol.mx/revaia/portal/pdf/2012/sept/l.pdf

26. LEE, Mark A. A global comparison of the nutritive values of forage plants grown in contrasting environments. En: Journal of Plant Research. 2018. vol I3I. P 64I-654. https://doi.org//0.1007/s/0265018-1024-y

27. LEYVA, Coralia S; VALDIVIE, M; ORTíZ, A.Utilization of fruit and leaf meals from breadfruit tree (Artocarpus altilis) for fattening New Zealand White rabbits. In: Pastos y Forrajes- 2012. vol 35. no. 4. $\mathrm{p}$ 443-452. http://scielo.sld.cu/scielo.php?script $=$ sci arttext\&pid=S0864-03942012000400009

28. LUKEFAHR, Steven D.; CHEEKE, PR. Rabbit project development strategies in subsistence farming systems: 2 Research applications. In:World Anim. Rev. vol 69. 1991 p. 26-35. https://Irrd.cipav.org.co/ Irrd2/3/cheeke2.htm

29. MEHREZ,A.Z.; MOUSA, M.R.M. Growth performance of rabbits fed olive pulp in North Sinai. In:Asian J.Anim. Sci. 201 I. vol.5 no 5. p $317-$ 329. https://doi.org//0.3923/ajas.2011.317.329

30. MOLINA, Edgar; GONZÁLEZ, Pedro; MORENO ROJAS, Rafael; MONTERO, Keyla; SÁNCHEZ, Adriana. Effect of the inclusion of amaranthus dubius in diets on carcass characteristics and meat quality of fatteing rabbits. In: Applied Animal Research. 2017. vol 46. p 218-223. https://doi.org/10.1080/097/2119.2017.1287078

31. MORA, Felipe Eugenio. Characterization of the Bore (alocasia macrorrhiza) and its use as an alternative food source for animals. In: Revista de Investigaciones Agroempresariales. 2015. vol I, p 96-I06. https://doi.org// 0.23850/25004468.3/3

32. MORA-VALVERDE, D. The use of mulberry (Morus alba) for rabbit feeding. The role of fiber and protein in the digestive tract. In: Agronomia mesoamericana. 2010. n 2, p 357-366. https://www. redalyc.org/pdf/437/43720093017.pdf
33. MORENO H. Caracterización del recurso alimenticio. El Bore (Alocasia macrorrhiza). Universidad Nacional de Colombia, Facultad de Medicina Veterinaria y Zootecnia, Bogotá. 2002. http:// www.buenastareas.com/ensayos/Caracterizacion-De-Bore-ComoRecurso-Alimenticio/844054.html

34. MUÑOZ VALDERRAMA, Jeyson. Características Generales y específicas del Bore (Alocasia macrorrhiza (Linneo), Schott) como alernativa para ser utilizado en la alimentación animal. [Diapositivas]. $6 \mathrm{I}$ diapositivas, color. 201I. https://prezi.com/_aexw80fishd/ caracteristicas-generales-y-especificas-del-bore-alocasiamacrorrhiza-linneo-schott-como-alternativa-para-ser-utilizado-en-laalimentacion-animal/

35. NEVER,Assan. Use of non-classical feed resources and their influence on some performance indicators in rabbits. In: Scientific Journal of Review. 2018. vol 7.p 563-57I. https://doi.org/10.14196/sjr.v7il.2492

36. A.O.A.C. Official Methods of Analysis. Association of official Analytical Chemist. EUA. 1995

37. ORTIZ, Abel; MOTTA FERREIRA, W.; ANCHIETA RAMÍREZ, M. MORAES HOSKEN, F.; LEZCANO, Pedro. Soybean meal substitution by torula yeast (candida utilis) grown on vinasses in pelleted diets for fattening rabbits. In: Revista Cubana de Ciencia Agrícola. 2013. vol. 47. no 4. p 389-393. https://cjascience.com/index.php/CJAS/article/ view/387

38. PALMA CASTILLO, Orlando Rafael; HURTADO, Ernesto Antonio. Productive behavior of rabbits during the period of growth-fattening fed with fruits of mango (Mangifera indica) in partial substitution of the balanced food commercial. In: Revista UDO Agrícola. 2009. no 9. p 33-37. https://tspace.library.utoronto.ca/bitstream//807/45542/// cg09113.pdf

39. QUINTERO,Victoria; GARCÍA, Genny; PELÁEZ,Angélica. Evaluation of gold-bud flour in diets for rabbits in growing stage. In: Acta Agron. 2007. vol 56. no 4, p. 203-206. http://www.scielo.org.co/scielo. php?script $=$ sci arttext\&pid $=S 0|20-28| 22007000400008$

40. READ, Theya; COMBES, Sylvie; GIDENNE, Thierry; DESTOMES, Nicolas; GRENET, L; FORTUN-LAMOTHE, L. Feed composition at the onset of feeding behaviour influences. In: Livestock science. 2016. p 97-102. https://doi.org/10.1016/j.livsci.2015.12.015

4I. RODRÍGUEZ PASTRANA, Héctor. El sacrificio y el procesamiento del conejo para auto consumo. 2002. Nota Técnica. Obtenido de http:// academic.uprm.edu/rodriguezh/HTMLobj-86/PROCESAMIENTO DEL_CONEJO_Traducido_y_Adaptado.pdf

42. TROCINO, Angela; FRAGKIADAKIS, M; MAJOLINI, D; TAZZOLI, M; RADIELLI, G; XICCATO, G. Soluble fibre, starch and protein level in diets for growing rabbits. En: Animal Feed Science and Technology. 2013. Vol 180. P 73-82. https://doi.org/l0.1016/j. anifeedsci.2013.01.007

43. ZWOLIOSKI, Cezary; GUGOŁEK, Andrzej; STRYCHALSKI, Janusz; KOWALSKA, Dorota; CHWASTOWSKA-SIWIECK, Iwona; KONSTANTYNOWICZ, Malgorzata. The effect of substitution of soybean meal with a mixture of rapeseed meal, white lupin grain, and pea grain on performance indicators, nutrient digestibility, and nitrogen retention in Popielno White rabbits. In: J. Appl. Anim. Res. 2017. vol 45. no. I. p. 570-576. https://doi.org//0.1080/097/21/9.201 6.1233107 